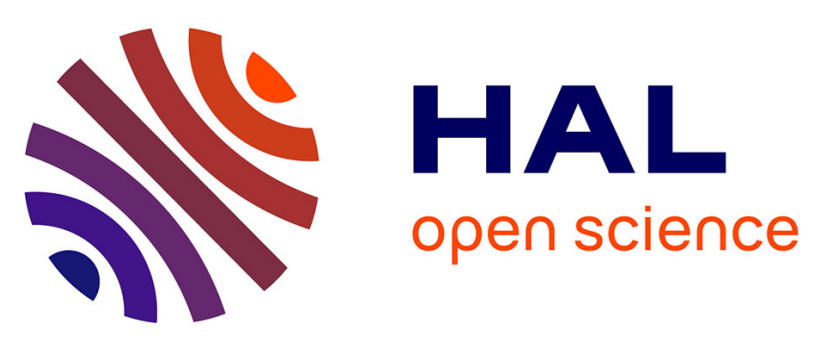

\title{
Numeric Methodology for Determining the Volumetric Consumption of Hydrated Ethanol in Flex-Fuel Vehicles
}

\author{
Marcelo K. Shibuya, Irenilza De Näas, Mario Mollo Neto
}

\section{To cite this version:}

Marcelo K. Shibuya, Irenilza De Näas, Mario Mollo Neto. Numeric Methodology for Determining the Volumetric Consumption of Hydrated Ethanol in Flex-Fuel Vehicles. IFIP International Conference on Advances in Production Management Systems (APMS), Sep 2015, Tokyo, Japan. pp.243-250, 10.1007/978-3-319-22756-6_30. hal-01417483

\section{HAL Id: hal-01417483 \\ https://hal.science/hal-01417483}

Submitted on 15 Dec 2016

HAL is a multi-disciplinary open access archive for the deposit and dissemination of scientific research documents, whether they are published or not. The documents may come from teaching and research institutions in France or abroad, or from public or private research centers.
L'archive ouverte pluridisciplinaire HAL, est destinée au dépôt et à la diffusion de documents scientifiques de niveau recherche, publiés ou non, émanant des établissements d'enseignement et de recherche français ou étrangers, des laboratoires publics ou privés. 


\title{
Numeric Methodology for Determining the Volumetric Consumption of Hydrated Ethanol in Flex-Fuel Vehicles
}

\author{
Marcelo K. Shibuya ${ }^{1}$, Irenilza de A. Näas ${ }^{1}$, Mario Mollo Neto ${ }^{2}$ \\ ${ }^{1}$ Paulista University-UNIP, Graduate Program in Production Engineering, Dr. Bacelar St. \\ 1212, São Paulo, Brazil \\ \{marcelo.shibuya@gmail.com, irenilza@gmail.com \\ ${ }^{2}$ UNESP - Campus Tupã, Domingos da Costa Lopes St., Tupã, Brazil \\ \{mariomollo@gmail.com $\}$
}

\begin{abstract}
The beginning of the manufacturing of the flex fuel vehicles in 2003, gave a new dynamic to fuel demand in Brazil. As the flex-fuel vehicles can be supplied with gasoline, hydrated ethanol or the mixture of the both in any proportion, the decision on which fuel to use occurs at the moment of supply, according to the most advantageous price and the consumer's preference. Considering this scenario, the objective of the present study was to obtain a calculation method to determine the fuel volume used by the flex-fuel vehicle fleet. For this purpose, the fuel conversion in energy units of oil barrels was used. The fuel demand by type of vehicle was obtained through the proportion of the number of vehicles and the distance traveled in the period. The results indicate that there was a behavioral change on fuel consumption by the users of the flex fuel fleet.
\end{abstract}

Keywords: Ethanol, Flex-Fuel Vehicles, Fuel demand.

\section{Introduction}

According to [1], in 2014, 3.1 million light vehicles were licensed in Brazil. Out of these 3.1 million automobiles, $95 \%$ are equipped with the flex fuel technology and the remaining $5 \%$ are powered by gasoline or ethanol. It is found in current literature $[2,3]$ that ethanol consumed by Brazilian vehicles may be anhydrous (mixed with gasoline in the proportion of 20 to $25 \%$, depending on the availability and price of biofuel in the market) and the hydrated ethanol. The gasoline mixed with anhydrous ethanol is named by the [4] as gasoline type C.

Brazil is the world's largest producer of ethanol from sugar cane[5], with the advantage that the climate is favorable for planting sugar cane. The biofuel production, concentrated in the Center-South region, favored the introduction and acceptance of the flex-fuel vehicles by consumers, and it is the region that has the largest fleet of automobiles. According to [6], flex-fuel vehicles have been replacing vehicles that are supplied by a single type of fuel (only gasoline or ethanol), enabling owners to choose the fuel with lower price at the gas station pump. This characteristic of the flex-fuel vehicles brings a new scenario in fuel consumption by the fleet of light vehicles in Brazil, as well as difficulties to estimate the fuel volumes consumed by these vehicles. 
In the current literature there are studies showing methods for determining future fuel consumption by using the correlation between the parity of prices between the two fuels and the fraction of hydrated ethanol relative to the total volume of fuel demanded by this fleet [7, 8, 9]. However, it lacks in information on the calculation method used to obtain the volume of hydrated ethanol and gasoline $\mathrm{C}$ consumed by flex fuel vehicles, based on the total amount of fuel consumed in a given period throughout the fleet.

This study aimed to develop a numerical calculation method for determining the fuel consumption by the flex-fuel vehicle fleet in Brazil. It is proposed to obtain the adequate volume of fuel consumed by the vehicle fleet of flex-fuel allowing studies to analyze the demand for behavior change due to the fuel price.

\section{The evolution of vehicle fleet of flex-fuel and the fuel demand in Brazil}

With the introduction of flex-fuel vehicles in Brazil in 2003, there was a significant change in the use of hydrated and anhydrous as propellant fuels. According to [10] and [11], anhydrous ethanol is the most important additive in gasoline and the hydrated ethanol can be used as an alternative fuel in flex-fuel vehicles, capable of being supplied with gasoline $\mathrm{C}$, hydrated ethanol or a mixture of both in any proportion.

Ethanol was introduced in the Brazilian energy matrix in 1975 through the Proalcool program (National Alcohol Program) whose objective was the large-scale production of fuels to replace fossil fuels used to supply the Brazilian fleet of vehicles $[11,12,13,14]$. The launch of the flex-fuel vehicles in 2003 gained rapid acceptance by the automobile owners by eliminating the risk of shortages, as it had happened to the owners of vehicles moved by ethanol in Proalcool time [15]. Besides reducing the oil dependency, the use of ethanol for vehicle supply reduces the emission of particulate matter, carbon monoxide and minimizes problems in the ozone layer [16].

The fleet of light vehicles consists of passenger and light commercial automobiles. Light commercial vehicles are vans and pick-ups [1]. As for supply, light vehicle fleet is composed of three types of engine, that is, with engines powered exclusively by gasoline $\mathrm{C}$, ethanol, and flex-fuel. On the National Atmospheric Emissions Inventory of Road Vehicles, published by [8], it was estimated that the fuel demand of the light vehicle fleet can be estimated by the quantity of vehicles circulating in the fleet, the intensity of use and fuel efficiency. The equation 1 shows the relationship between these variables.

$$
C_{V i}=\frac{Q_{V i} x I_{V i}}{R_{V i}}
$$

where $\mathrm{C}_{\mathrm{V}_{\mathrm{i}}}$ : fuel demand for a given type of vehicle, $\mathrm{Q}_{\mathrm{vi}}$ : number of vehicles that are effectively circulating in the given fleet, $\mathrm{I}_{\mathrm{V}}$ : use intensity for a given type of vehicle and $\mathrm{R}_{\mathrm{Vi}}$ : is the fuel efficiency for a given type of vehicle. 
The Equation 2 and 3 show respectively, the mathematical functions for the fraction remaining vehicles of the fleet [8] and the average age of the vehicles fleet.

$$
\begin{aligned}
& S(t)=1-\exp (-\exp (1,798-0,137(t))) \\
& A_{n}=\frac{\sum_{i=0}^{n}\left(V_{i} x A_{i}\right)}{\sum_{i=0}^{n} V_{i}}
\end{aligned}
$$

where $S(t)$ : remaining vehicles of a given fleet, $t$ : average age of the fleet, $A_{n}$ : mean age in a specific year, Vi: quantity of vehicles for a given type of fleet, Ai: age of the fleet in a given year.

Replacing gasoline with ethanol at the time of filling will only constitutes an advantage to the consumer if the ratio of the price of biofuel compared to the price of gasoline is less than 70\% [10] and [17]. This price relationship is related to the difference between the calorific values of these fuels. The [18] defines that a cubic meter of hydrated ethanol has $5,096 \times 10^{3} \mathrm{kcal}$ and is equivalent to 3.59 oil barrels, and a cubic meter of gasoline $\mathrm{C}$ has $7,106 \times 10^{3} \mathrm{kcal}$ and is equivalent to 5.42 oil barrels.

The figure 1 shows the fuel consumption and fleet evolution of light vehicles used in Brazil, comprehending the period from 2003 to 2013.

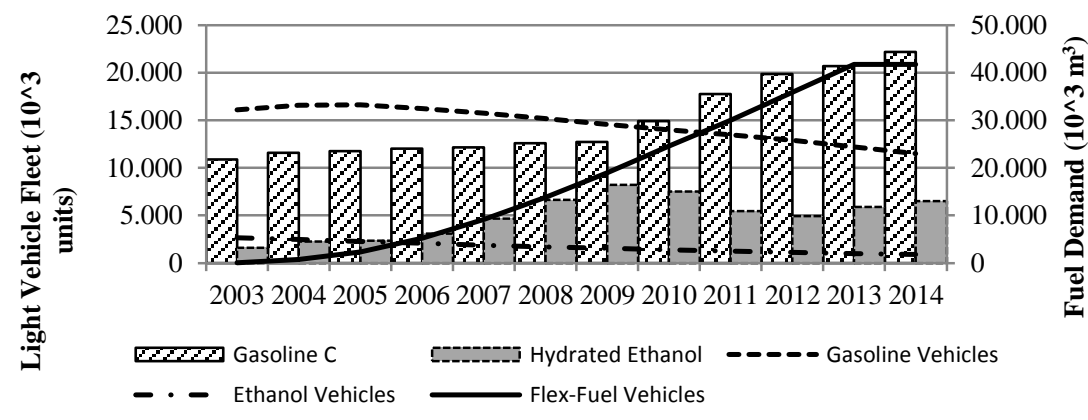

Fig. 1: Fleet of light vehicles and fuel demand in (Source: [1], [4], [8])

The increased consumption of fossil fuels and the reduction of biofuel demand from the year of 2009, showed in Figure 1, is considered as a phase of stagnation and halt of the sugarcane industry expansion in Brazil [3]; [7]; [19]. The same authors add that the government intervention in gasoline prices since 2008, in order to combat inflation in the country, contributed to this phase of stagnation, making its marketed price lower than the oil barrel price.

From 2007 to 2013 (Figure 2), the annual production volumes of gasoline A (gasoline pure without additive), ethanol (including anhydrous and hydrated) and their respective imports indicate that, from the year of 2009 forward, there was an increase in the production and importation of gasoline A, to supply the rise in gasoline $\mathrm{C}$ demand by the light vehicle fleet. On the same graph, it is possible to perceive that, from the year of 2010, Brazil starts to import ethanol to supply the domestic demand. 


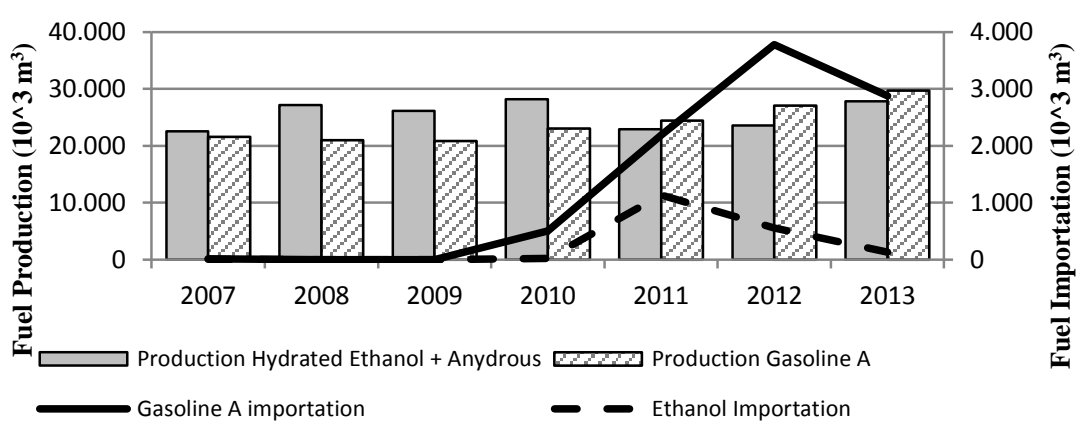

Fig. 2: gasoline A and ethanol production and importation Graph (Source: [4])

The use intensity of automotive light vehicles, including cars and light commercial is defined by [8]. The present study shows that the distance traveled by a light vehicle in one year varies according to its age. The equation 4 defines the mathematical function which expresses the use intensity.

$I_{\text {use }}=19.400-600(t-1)$, to $t \geq 1$ or $I_{\text {use }}=16330 \times t$ to $t<1$

where $I_{\text {use }}$ is the use intensity in $\mathrm{km} /$ year and t is the age of the vehicle in year.

\section{Methodology}

The annual demand for hydrated ethanol and gasoline $\mathrm{C}$ were obtained from the data provided by the [4], and the annual quantities of licensed vehicles were obtained from [1]. The study included the determination of the fuels used by flex-fuel vehicles in the period of 2006 to 2014.

The volumes of hydrated ethanol and gasoline $\mathrm{C}$ were convertes into a single unit of calorific value, choosing the for this, the Barrel of Oil Equivalent (BOE). Thus, with the same power measurement unit in volume of the fuels, it was possibility to perform the mathematical operations of both fuels, without the conversions needs.

The annual volumes of gasoline $\mathrm{C}$ and hydrated ethanol demanded by the vehicles were calculated by converting the annual volumes of gasoline $\mathrm{C}$ and hydrated ethanol in $\mathrm{BOE}$ volumes. The total consumption $(\mathrm{Ct})$ of fuels can be expressed by Equation 5 .

$$
C_{t}=C_{V G}+C_{V E}+C_{V F(\text { gas })}+C_{V F(\text { ethanol })}
$$

The volumes of fuels supplied by the fleet (Gasoline $\mathrm{C}$ or hydrated ethanol) can be further expressed by Equations 6, 7, 8 and 9:

$$
\begin{aligned}
& C_{t}=C_{t(G)}+C_{t(E)} \\
& C_{t(G)}=C_{V G}+C_{V F(\text { gas })}
\end{aligned}
$$




$$
\begin{aligned}
& C_{t(E)}=C_{V E}+C_{V F(\text { Ethanol })} \\
& C_{V F}=C_{V F(\text { gas })}+C_{V F(\text { Ethanol })}
\end{aligned}
$$

where $\mathrm{C}_{\mathrm{t}}$ : total fuel consumption in a given period; $\mathrm{C}_{\mathrm{t}(\mathrm{E})}$; total ethanol consumption in a given period; $\mathrm{C}_{\mathrm{t}(\mathrm{G})}$ : total gasoline $\mathrm{C}$ consumption in a given period; $\mathrm{C}_{\mathrm{VG}}$ : total consumption of gasoline $\mathrm{C}$ by the fleet of vehicles moved by gasoline; $\mathrm{C}_{\mathrm{VD}}$ : total consumption of hydrated ethanol by the fleet of vehicles moved by ethanol; $\mathrm{C}_{\mathrm{VF}}$ : total consumption of fuel (gasoline $\mathrm{C}$ e hydrated ethanol) by the flex fuel vehicles; $\mathrm{C}_{\mathrm{VF} \text { (gas) }}$ : gasoline fuel consumption by the fleet of flex-fuel vehicles and $\mathrm{C}_{\mathrm{VF}(\mathrm{ethanol})}$ : total ethanol fuel consumption by the fleet of flex-fuel vehicles.

By substituting Equation 1 on Equation 4, Equation 9 is obtained:

$$
C_{t}=\frac{Q_{V G} x I_{V g}}{R_{V G}}+\frac{Q_{V E} x I_{V E}}{R_{V E}}+\frac{Q_{V F} x I_{V i} x(1-E \%)}{R_{V F}}+\frac{Q_{V i} x I_{V i} x E \%}{R_{V F}}
$$

Considering that the volumes of fuel were expressed in the same unit of energy, it can be considered that the income data in kilometers per unit of BOE for the vehicles powered with gasoline, ethanol and flex-fuel are similar. Thus, it can be defined that the volumes of fuel demanded by the vehicles in the fleet (Equation 10) is proportional to the amount of fleet vehicles multiplied by its respective use intensity. The volumes of gasoline $\mathrm{C}$ and hydrated ethanol consumed by the light vehicle fleet were obtained with the aid of a calculation spreadsheet (Excel).

\section{Results and discussion}

Figure 3 shows that from the year of 2011 on the flex-fuel vehicles have become most of vehicle fleet, as reported by [6].

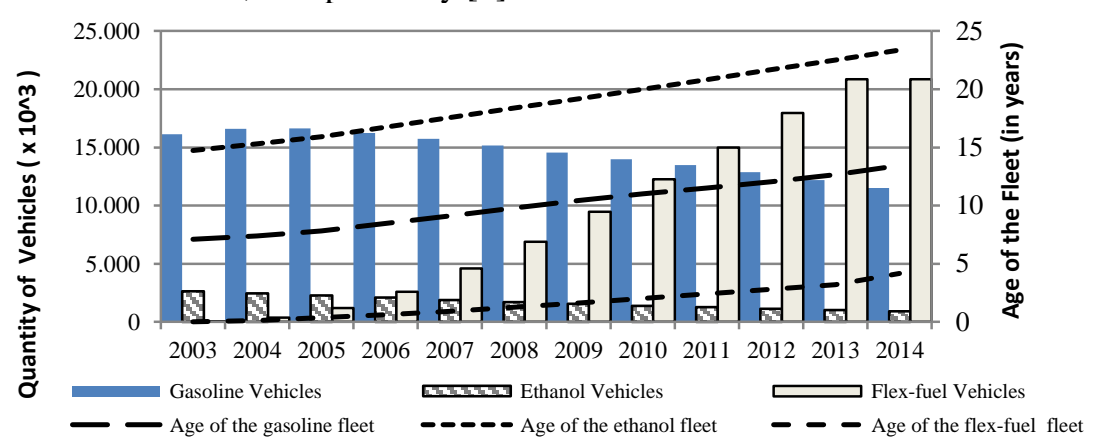

Fig. 3: Variation of the vehicle fleet in circulation in Brazil.

Analyzing the age evolution of the vehicle fleet, calculated by Equation 3 [8], we can see that the flex-fuel vehicle fleet has the lowest age in 2014 (4.18 years). The gasoline vehicles fleet has the age of 13.45 years and the ethanol vehicles fleet of has 23.36 years. The age of flex-fuel vehicle fleet suggests that these vehicles are respon- 
sible for the consumption of a greater share of automotive fuels in Brazil. The results obtained for the fuel consumed by the Brazilian fleet of light vehicles (Figure 4) were initially calculated in BOE and converted into cubic meters of gasoline $\mathrm{C}$ or hydrated ethanol, for their respective fuel supplied to each type of vehicle in the light vehicle fleet.

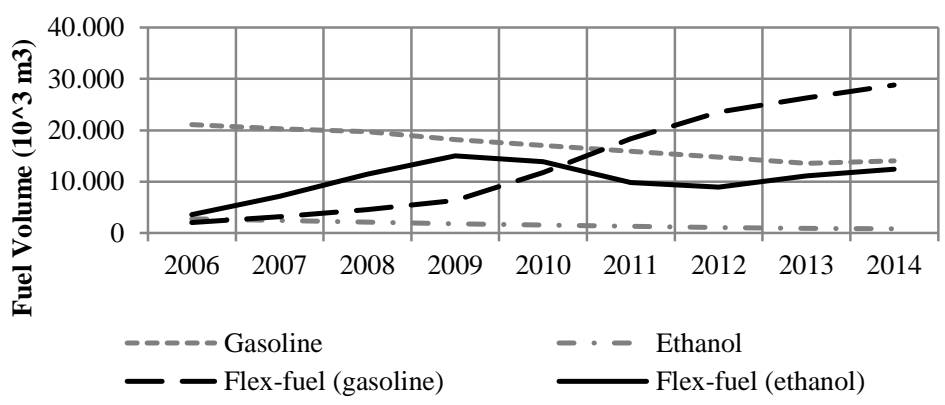

Fig. 4: Fuel consumption by the Brazilian vehicle fleet

A significant increase in the consumption of gasoline $\mathrm{C}$ by the flex-fuel vehicles was noticed (Figure 5). The volume increased from 2.074 million cubic meters in 2006 to 28.787 million cubic meters in 2014. It is also seen an increase in hydrated ethanol consumption by flex-fuel vehicles between 2006 and 2009, and a demand reduction from 2010. These results suggest that the owners of flex-fuel vehicles began to prefer the fossil fuel, against the use of biofuel. These numbers desagrees with other findings [3; 7; 19] which had determined that 2009 was the beginning of stagnating of the sugarcane industry in Brazil, with the consequences the interruption of the expansion of ethanol plnts and the reduction of the biofuel supply. The percentage of gasoline $\mathrm{C}$ consumed volume in relation to the total amount of fuel consumed by flex-fuel vehicles had definite change in the fuel demand, such as the increased gasoline C consumption, from $36.7 \%$ in 2006 to $69.8 \%$ in 2014 (Figure 6).

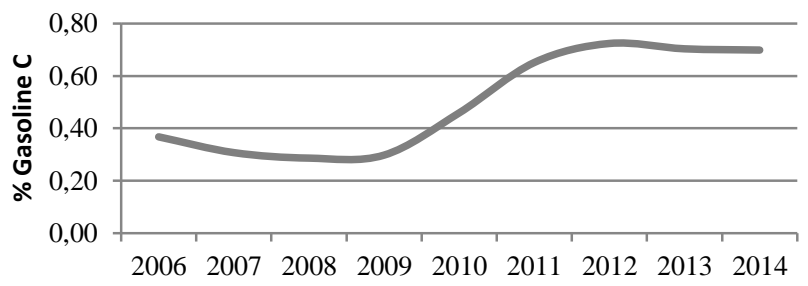

Fig. 6: Percentage of gasoline $\mathrm{C}$ consumed by the flex fuel vehicles

The increased consumption of gasoline $\mathrm{C}$ and the consequent decrease of the biofuel demand during the study period may have been caused by the artificial maintenance of the gasoline $\mathrm{C}$ prices $[3 ; 7 ; 19]$ and it can bring two serious consequences to the Brazilian energy sector. The first would be the deepening crisis in the Brazilian ethanol industry, with the closure of ethanol's plants. Referring to [20], from 2009 to 2014, 51 units have closed down their activities, and 18 new units 
started their operations. It is a negative balance compared to the amount of flex-fuel vehicles, most of the Brazilian light vehicle fleet, released by [19], which enhance the biofuel demand. The second consequence is, if gasoline $\mathrm{C}$ consumption rate is maintained at levels similar to the period 2011-2014 (Figure 6), it might cause a growing need to import this fuel, as disclosed by [4]. Finally, another factor that should not be ignored is the ecologic benefits brought by the use of biofuels, such as the reduction of particulate matter, greenhouse gases including carbon monoxide [16]. The maintenance of these high rates gasoline $\mathrm{C}$ use by the flex-fuel vehicles can minimize these benefits and worsen air quality of Brazilian cities

\section{Conclusion}

Using the numeric methodology proposed in this study, it was possible to estimate the annual volumes of gasoline $\mathrm{C}$ and hydrated ethanol consumed by the flexfuel vehicle fleet in Brazil. The study covered the period from 2006 to 2014 and allowed to identify changes in the demand for fuels used by flex-fuel vehicles. With the volumes of fuels obtained, the demand (in percentage) curve for gasoline $\mathrm{C}$ was determined, where it was possible to identify the change in consumption of the fuel from 2010 forward.

Although there are several causes related to the crisis established in the sugar cane industry, and the consequent change in the fuel demand, it is important to point out that the lack of an energy policy in Brazil may have been their primary factor for the controversial success in the use of flex-fuel vehicles. Maintainning the demand for hydrated ethanol within the same levels of the period of 2006-2010, would bring various benefits to Brazil, such as the return of the Brazilian sugarcane sector growth, job growth in the supply chain, the reduction of oil dependency and finally, the improvement of air quality due to the replacement of fossil fuel by biodiesel. The numeric calculation methodology reported in this study could be used to determine the hydrated ethanol consumption mathematical function on the basis of price parity between hydrated ethanol and gasoline $\mathrm{C}$.

The mathematical function could be used to predict the fuel demand for the light vehicle fleet, allowing it to anticipate the volumes to be consumed, and the make production planning and infrastructure necessary for the supply of such products in the Brazilian fuel market.

\section{References}

1. ANFAVEA - Associação Nacional dos Fabricantes de Veículos Automotores, Anuário da Indústria Automobilística Brasileira, 2015

2. Bake, J. D. V. D. W, Junginger M., Faaij, A. Poot, T., Walter, A. Explaining the experience curve: cost reductions of Brazilian ethanol from sugarcane, Biomass and Bioenergy 33, pg 644-658, 2009. 
3. Nogueira, L. A. H; Capaz, R. S.; Biofuels in Brazil: Evolution, Achievements and Perspectives on Food Security; Global Food Security 2; pg 117-125; 2013.

4. ANP - Agência Nacional do Petróleo, Anuário Estatístico 2014, disponível em http://www.anp.gov.br/, nov/2014.

5. Martinez, S. H., Eijck, J. V., Cunha, M. P., Guilhoto, J. J. M., Walter, A., Faaij, A.; Analysis of socio-economic impacts of sustainable sugarcane ethanol production by means of inter-organizational Input-Output analysis demonstrate of North-East of Brazil ; Renewable and Sustainable Energy Reviews 28; pg. 290-316; 2013.

6. Du, X., Carriquiry, M.A., Flex-fuel vehicle adoption and dynamics of ethanol prices: lessons from Brazil. Energy Policy (2013), http://dx.doi.org/10.1016/j.enpol.2013.04.008i

7. EPE - Empresa de Pesquisa Energética. Avaliação do Comportamento dos Usuários de Veículos Flex-Fuel no Consumo de Combustíveis no Brasil - Brasília, 2013.

8. MMA (Ministério do Meio Ambiente), Inventário Nacional de Emissões Atmosféricas por Veículos Automotores Rodoviários, Brasília/Brasil, 2014.

9. Losekann, L., Vilela, T., Castro, G. R..;Difusão de Automóveis Flexíveis no Brasil: Sensibilidade ao Preço e Impactos na Emissão de $\mathrm{CO}_{2}$; Instituto Brasileiro do Petróleo, 2012.

10. Freitas, L. C., Kaneko, S., Ethanol Demand under Flex-fuel Technology Regime in Brasil, Energy Economics 33, pg 1146-1154, 2011.

11. BNDES. Bioetanol de cana-de-açúcar: energia para o desenvolvimento sustentável - Rio de Janeiro, 2008.

12. Hira, A.; Sugar Rush: Prospects for a Global Ethanol Market; Energy Police 39; pg. 69256935; 2011.

13. Crago C. L., Khanna, M., Barton, J., Giuliani, E., Amaral, W., Competitiveness of Brazilian sugarcane ethanol compared to US corn ethanol, Energy Policy 38, pg7404-7415, 2010.

14. Santos, G. F., Fuel Demand in Brazil in a Dynamic Panel Data Approach, Energy Economics 36, pg 229-240, 2013.

15. Stattman, S. L., Hospes, O., Mol, A. P. J., Governing Biofuels in Brazil: a comparison of ethanol and biodiesel policy, Energy Policy 61, pg 22-30, 2013.

16. Mollo Neto, M.; Vendrametto, O.; Walker, R. A. Is the Development of Brazilian Biofuel Network Sustainable? International Conference on Advances in Production Management Systems (APMS 2010). Vienna: Springer, 2010.

17. Goldemberg, J., Coelho, S. T., Lucon, O., Guardabassi, P.; Brazilian sugarcane ethanol: lessons learned; Energy Police 39; pg. 6925-6935; 2011.

18. EPE - Empresa de Pesquisa Energética, Conversor de Unidades, disponível em http://www.ipeadata.gov.br/, consultado em nov/2014.

19. Milanez, A. Y., Nyko D., Garcia, J. L. F., Reis, B. L. S. F. S.; O déficit de produção de etanol no Brasil entre 2012 e 2015: determinantes, consequências e sugestões de política. BNDES. Rio de Janeiro, 2012.

20. UNICA - União da Indústria da Cana de Açúcar; Relatório Final da Safra 2013-2014, disponível em http://www.unicadata.com.br/listagem.php?idMn=88, access in 12/02/2015. 